JPPUMA: Jurnal Ilmu Pemerintahan dan Sosial Politik UMA Uournal of Governance and Political Social

UMA), 8 (1) (2020): 9-17, DOI: https://doi.org/10.31289/ippuma.v8i1.2886

JPPUMA: Jurnal Ilmu Pemerintahan dan Sosial Politik UMA

(Journal of Governance and Political Social UMA)

Available online http://ois.uma.ac.id/index.php/ippuma

\title{
Power Relations in Developing Bussiness of Cattle Farm in the District of West Tasifeto, Belu Regency, Indonesia's East Nusa Tenggara Province
}

\author{
Adeodata Mbiri'1) \& Kushandajani ${ }^{2)}$ \\ 1) Masters in Political Science, Faculty of Social and Political Sciences, \\ Universitas Diponegoro, Indonesia \\ 2) Department of Politics and Government Science, Universitas Diponegoro, Indonesia
}

Recieved: September 14, 2019; Accepted: February 21, 2020; Published: May 11, 2020

\begin{abstract}
This research aims to analyze power relations between actors in developing local commodities through a cattle farm in the District of West Tasifeto, the Regency of Belu. The author applies descriptive qualitative research methods in disentangling power relations between actors who play their roles in drafting Belu's Local Regulation (Peraturan Daerah/Perda) No. 6 of 2011. In collecting data, the author employs a qualitative approach, namely observation, and interviews with local farmers, Melus ethnic communities, Belu Regency's government (Department of Farming Affairs), Local Businessmen, and secondary data from various documents. This study reveals that there are power relations among actors, namely local farmers, local authorities (Department of Farming Affairs, Belu Regency), and local businessmen, which are indicated by three indicators in drafting local regulation, selecting the farming area, and marketing the cattle products. Within these power relations, the actors influence each other at every moment and every connection. A strategy that is employed is not violence. Rather, it is through social relations and regulation system to promote various interests through politics of law, legal drafting, to enact a local regulation (Peraturan Daerah/Perda). Business people's interests and political interests have been imposed in this process of extending local commodities, which compete with the local farmers interests that less impacted by the government's project. Therefore, the expansion of local commodities through a cattle farm in West Tasifeto results in the complexity of power relations interplaying with each other.
\end{abstract}

Keywords: Power Relations, Business, Politics.

How to cite: Mbiri, A \& Kushandajani (2020), Power Relations in Developing Bussiness of Cattle Farm in the District of West Tasifeto, Belu Regency, Indonesia's East Nusa Tenggara Province, JPPUMA: Jurnal Ilmu Pemerintahan dan Sosial Politik UMA (Journal of Governance and Political Social UMA), 8 (1): 9-17.

*Corresponding author:

E-mail: lanijanuari00@gmail.com
ISSN 2549-1660 (Print)

ISSN 2550-1305 (Online) 


\section{INTRODUCTION}

Power is a complicated strategic model in a certain society formed by separated micro powers. Power is not possessed by a certain subject but there is potential in everyone as a strategy. Thus, it is omnipresent eventually (Neno, 2015).

Power works along with different potentials. It presents due to the difference in which subjects develop relationships and networks. Power emerges in it and manifests in many forms, such as social relations, regulations, and social institutions. According to Foucault, power strategy does not work through oppression, but normalization (control) and regulation (order) (Neno, 2015).

Power can be understood as anything that preserves the relations. It creates a chain or system, which could separate one or groups from another system of power relations. Simply, power is a strategy that causes power relations. Power is constantly produced in every moment and every social relation. The omnipresence of power is not due to controlling everything, rather because it comes from everywhere (Kamahi, 2017).

Foucault (1990) states that there are five propositions on what he means about power. First, power is not anything that could be obtained, possessed and given as an object that can be held or extinct. Rather, it is driven from anywhere by dynamic relations. Second, power relation is not a structural and hierarchical relationship that presupposes the twosides relation of the master and the overpowered. Third, power comes from below, which presupposes that there is no distinction in the binary opposition model because power includes both sides. Fourth, the power relation is intentional and nonsubjective. Fifth, where there is power, there is also resistance. Also, resistance does not exist outside the power relation. Those who are within the power relation, there is no way out of it.
The Indonesian government attempts to accelerate self-sufficiency in livestock, which concentrate in 18 provinces. One of which is the Province of East Nusa Tenggara, precisely in the Regency of Belu. The regency holds a local commodity from a cattle farm. Belu has great potential in the farming sector, as shown in the following table.

Table 2

Quantity of cattle in Belu Regency per District

\begin{tabular}{|c|c|c|c|c|}
\hline \multirow[t]{2}{*}{ No } & \multirow[t]{2}{*}{ District } & \multicolumn{3}{|l|}{ Year } \\
\hline & & 2014 & 2015 & 2016 \\
\hline 1 & Raimanuk & 7,362 & 7,465 & 8,913 \\
\hline 2 & Tasifeto barat & 8,025 & 8,137 & 8,948 \\
\hline 3 & Kakuluk mesak & 5,373 & 5,549 & 8,188 \\
\hline 4 & Nanaet duabesi & 4,235 & 4294 & 4,738 \\
\hline 5 & Kota atambua & 1,186 & 1,202 & 1,063 \\
\hline 6 & Atambua barat & 1,352 & 1,271 & 1,374 \\
\hline 7 & $\begin{array}{l}\text { Atambua } \\
\text { selatan }\end{array}$ & 384 & 389 & 774 \\
\hline 8 & Tasifeto timur & 7,456 & 7,569 & 13,124 \\
\hline 9 & Raihat & 5,462 & 5,538 & 5,104 \\
\hline 10 & Lasiolat & 5,210 & 5,283 & 4,141 \\
\hline 11 & Lamaknen & 5,518 & 5,596 & 6,433 \\
\hline 12 & $\begin{array}{l}\text { Lamaknen } \\
\text { selatan }\end{array}$ & 4,921 & 4,990 & 5,792 \\
\hline Sum & & $\begin{array}{l}56,49 \\
3\end{array}$ & 57,383 & $\begin{array}{l}68,59 \\
2\end{array}$ \\
\hline
\end{tabular}

Sources: Central Agency of Statistics (BPS) Belu Regency 2017

The above table illustrates the increase in the population of cattle. Belu also encourages the program for selfsufficiency by developing farm area. The farming region in Belu is called as the area of sonis laloran. It is made officially following local regulation, Perda, No. 6 of 2011 on spatial planning of Belu Regency 2011-2031. In Chapter five, article 29 point 1 (d) specifies a strategic economic zone. Sonis Laloran is set as a strategic area because of its roles in promoting the economic sector and encouraging the prosperity of local farmers.

Farming area or sonis laloran is located in the District of West Tasifeto, precisely on the traditional land (tanah adat, ulayat) from the ethnic group of Melus. The chief of the group (Ketua Suku) 
has lent in 2007 the land to the local government of Belu Regency to be utilized, which was commenced in 2013.

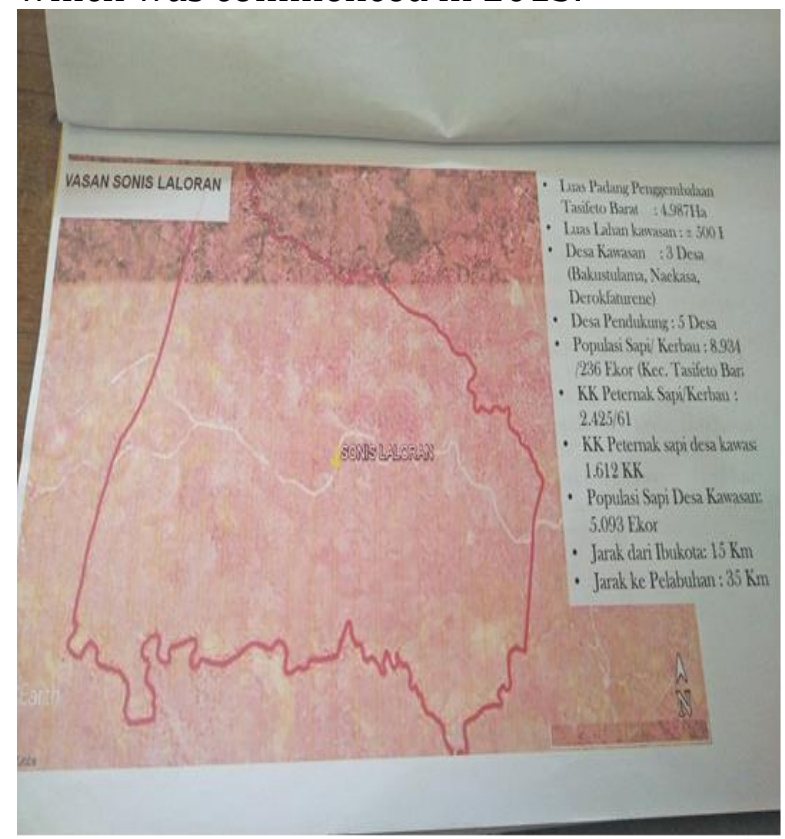

Figure 1 Cattle Farming area (Sosis Laloran) Source: Department of Farming Affairs, Belu Regency

It has been already 15 years but this zone has not been developed well as a farming area (Belebau, 2018). It becomes obvious as the department's staff working in the district of Tasifeto Barat reveal that the development of this area has not yet been improved properly as planned although the Department of Farming Affairs has allocated local budget from the local administration (Elan, 2018).

The development of the sonis laloran area has been expected to encourage local cattle farming to improve the prosperity of the people, local farmers, and generally the local economy of Belu Regency. However, the implementation has not achieved yet ambition. Can the development of the farming area in the West Tasifeto improve the economy of the local farmers and other related stakeholders?

The decision to choose West Tasifeto as a cattle farming area has been politicized and resulted in dynamics configured by political elites, civil society, government (department of farming affairs), businessmen. In this context, the area has been a strategic economic object.
In the dynamics of scrambling for a benefit from farming, who have taken advantage of its development?

According to Foucault, power has been conceived as various relations spreading like a network. The power has to be looked at by understanding how it works or in what way it is operated. It has to be conceived as a thing that preserves the power relations, which form a chain or system of power. It can also divide a system from the other system of power relations. In sum, power is a strategy that results in power relations (Mudhoffir, 2013).

Power is a concept connected to the behavior. Where action can build a relation, so does the relation exist and work constantly (Kamahi, 2017). Therefore, the work of a government's program is determined by the political aspect that is related to the political and social reality at the local level.

The above explanation indicates that power is spreading everywhere, including in the expansion of local commodities through cattle farming in West Tasifeto. There have been power relations among local farmers and authorities (department of farming affairs). The relations among actors have been generated at every moment. They have been configured by strategy playing with social, political connections, such as in the arena of legal drafting or legislative system producing regulation.

Power is operating through social relations and regulation system, and not by oppression. The making of sonis laloran epitomizes the process in which social and political relations have been operating in enacting Local Regulation No. 6 of 2011. It is like selecting the area for farming, which the local community of ethnic Melus and the local government have been involved in power relations. Simply put, how do the relations work? 


\section{RESEARCH METHOD}

This research concentrates on the District of West Tasifeto, Belu Regency, which focuses on the power relations in attempts to develop cattle farm. This study applies descriptive-qualitative methods by observation in the area of farming or sonis laloran in the Village of Bakustulama. The interview has been conducted to some interviewees from the Department of Farming Affairs, local farmer groups, chief of Melus ethnic group who has authority over traditional land. The author looks also at some documents that can support the investigation, such as relevant publication, government reports and local regulations connected to sonis laloran.

Data have been analyzed with the linear and hierarchical approach, or bottom-up, which is interconnected with each other (Creswell, 2014). The subject of this research consists of local farmers, government agencies, traditional leaders, local political leaders, and businessmen from enterprises.

\section{RESULT AND DISCUSSION Legislation process of local regulation No. 6 of 2011}

In the decentralized political system in Indonesia, the regional government has been given autonomy to organize its local governance-politics, bureaucracy and financial. With this authority, the regional government organizes local administration and create public policy, either to improve public services or to encourage public participation in development.

Regional Parliament (DPRD) and the government can draft a bill for local regulation (Darmo, 2019). The local regulation, Perda, No. 6 of 2011 on spatial planning of Belu Regency 2011-2031 regulates strategic area for the economy, in which sonis laloran as large as 500 hectares have been entitled to become a cattle farming area (Kawasan Usaha Peternakan). The legislation process has been configured by power relations played by groups or institutions, such as the Local Parliament, the Regent, the Department of Farming Affairs, and the local farmers, in which they promote and impose their interests.

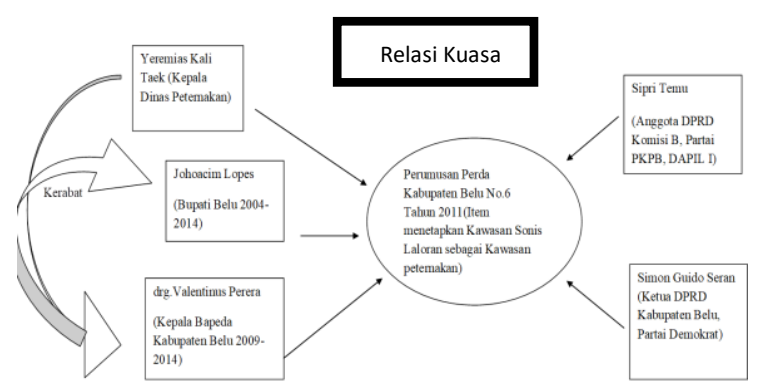

Figure 2. Power Relation in Legal Drafting of Perda No 6 of 2011. Source: combined by the author.

The above figure indicates the power relations among actors connected with political hierarchy and structural. Started with the announcement of the regional development plan, conveyed by the Department of Farming Affairs (led by Yeremias Kali) to both the Development Planning Board (BAPPEDA) (led by drg. Valentinus Pareira) and the Regent of Belu 2004-2014 Joachim Lopez. The concern of the department is to pursue its vision of self-sufficiency and quality livestock through optimization in utilizing local resources to encourage beef-cattle marketing in Belu Regency.

The decline of the marketing of farm products is related to two basic elements, namely local farmers as producers, which at the same time acting as the local seller as well as exporter. It is, therefore, developing the farming area is considered as a solution. The secretary of the Department of Farming Affairs Amandus Linci explicates that:

"When the pasture field is narrowing down, the availability of feed becomes less and less, and the quality of beef cattle is decreasing drastically and so is its marketing." 


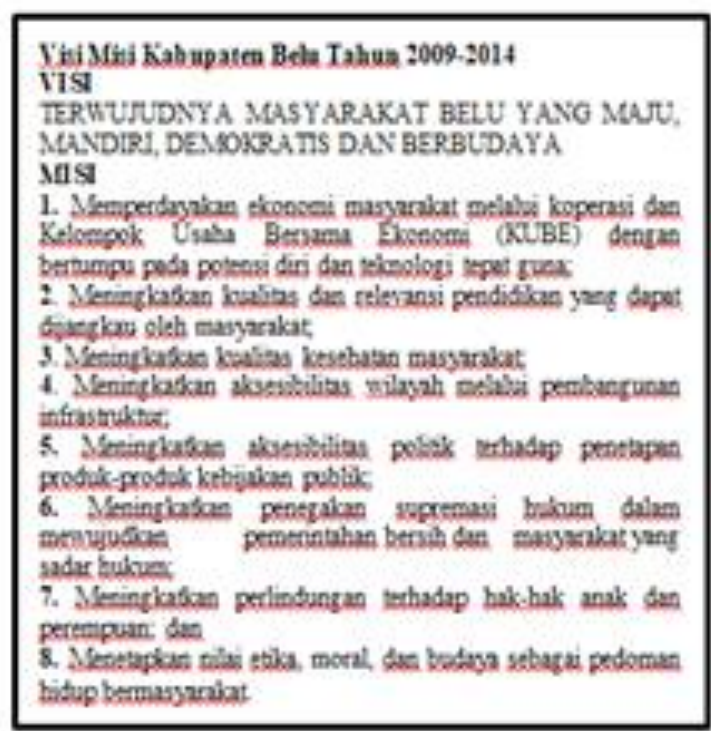

Figure 3. Vision and Mission of Belu Regency 2009-2014

Sonis laloran has been accepted by BAPPEDA and the Regent of Belu due to considered to be in line with the vision and mission of the regent in empowering the economy of the people through the economic community's work (KUBE) relying on their potential and relevant technology. In this context, this farming area is regarded as a way to encourage the West Tasifeto community's economy based on its resources as farmers.

The power relations that affect policymaking is in the process of developing the farming area, sonis laloran. The West Tasifeto has been chosen as a farming area due to political consideration. The district is the place of origin of Belu's Regent Joachim Lopez, which is also the basis of his constituents in the local election. The decision to choose the district shows political interests as part of the negotiation with the voters or supporters, which at the same time promote economic development.

The head of BAPPEDA drg. Valentinus is a close person to Joachim Lopez who has a position in bureaucracy. Lopez himself has a carrier background in bureaucracy, as the former head of BAPPEDA in 1999 and the Secretary of Local Administration in 2001-2003. In 2010, when he took an office in the second term as regent, Lopez appointed Valentinus as the head of BAPPEDA of Belu Regency.

Their relationship is going further in the political arena. After his reign in two terms, Joachim supported Valentinus and Cyprianus Temu (with an acronym VANSMU NKRI) from National Democratic Party in their candidacy to run in the local election for Belu Regent 2015-2020. Valentinus conveys that:

"Joachim invokes people of Belu to solidify themselves to support these candidates because they are suitable and harmonious candidates in developing Belu Regency soon".

The development planning of the farming area sonis laloran has been approved through the proposal and the promotion in the bureaucratic institution, which is highly political. Then, this plan has been brought to the legislation process in local parliament to legislate the Local Regulation No. 6 of 2011 on Spatial Planning of the Region of Belu Regency 2011-2013 on 2 August 2011. In the plenary meeting of the parliament, the point on establishing the farming area sonis laloran by the economic consideration has been put in Chapter 5, article 29 paragraph 1.

This plan has been supported by the legislator Cyprianus Temu, a member of Commission III Local Parliament 20092014 from PKPB (Partai Karya Peduli Bangsa). His constituency is from the District of West Tasifeto, which has been approved to become farming area sonis laloran. Implicitly, the interests behind Sipri Temu are to accommodate the aspiration and demand from the constituents to develop their area. Besides, the relationship between Sipri Temu and Joachim is quite close in the political arena. Sipri Temu is the head of a political party that nominates Joachim in the local election for the regent of Belu in the source od 2004-2014. Likewise, Joachim promoted Cyprianus as the candidate of Deputy Regent 2015-2020. 
The development of this farming area has also been supported by the spokesman of the Local Parliament (in term 20092014) Simon Guido Seran SH from Democratic Party, in the constituency of Belu I. The district of his constituency is including the area of sonis laloran. This shows the interests of the actor as a member of the local parliament in accommodating his constituents' aspirations and realizing it through a development project. Also, Simon Guido Seran is taking a position in the Democratic Party that nominated Joachim Lopez as the Regent of Belu. The party is led by Willybrodus Lay, who is the owner of one of a company in the sonis laloran cattle-farming area.

After passing through crucial debate in imposing various interests, this point was approved and agreed in the plenary meeting of the local parliament. When Joachim stepped down from office in 2014 based on the Decree of Minister of Home Affairs, Wellem Foni had been appointed to take the office based on the Decree of Minister of Home Affairs No. 131.53-1.338 in 2014, on 27 March 2014.

\section{The Selection of Location for Farming Area}

The land has been interesting since long ago as valuable resources. It is often related to power and territoriality, in which the power of a king is often indicated by the wide range of territory under his rule. A noble for instance has been said as wealthy if he owns a large land. Land often becomes a target, main resource, for power and wealth of a regime or dynasty.

In the modern age, the land has high economic values and becomes an asset having values for investment, which tend to increase constantly. The development going continuously in the frame of the global market demands physical infrastructures that need land. The values of land increase and it is also followed by interests and problems around it.

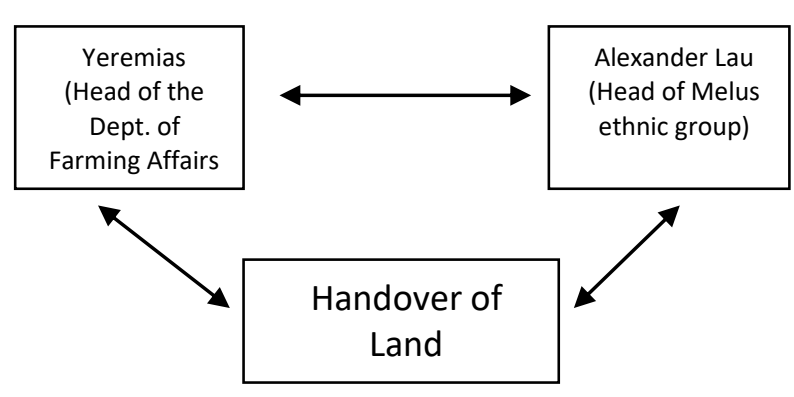

Figure 3. Power relations in the selection of the location for cattle farming area sonis laloran sources: combined by the author.

The farming area sonis laloran is not free from tensions and power relations since long ago. It is traditional land, which is inherited as a communal asset from generation to generation and preserved by the chief of the community. The land of the farming arena is possessed by Melus ethnic group led by Alexander Lau.

The members of Melus ethnic group scrambled for the land. They took pieces of it and have sold it secretly for personal interests, which then, stimulate internal conflict in the community. The traditional leader is needed to solve the conflict and to take any decision for resolution. The leader leads the negotiation involving community members.

Concomitantly with the internal dispute of Melus ethnic over land tenure, the government's plan in the development of farming area takes an effect. At this point, the head of the Department of Farming Affairs Yeremias approached the traditional leader (Kepala Suku) directly by visiting him at home. There Yeremias offered the plan to develop a farming area in the district of West Tasifeto.

Mikhael, the chief of management of farming area sonis laloran states that:

"This 'range' has taken its form from the former head of department Mr. Yerem, who thought that the pasture field has been narrowing, so there has to be a special zone in Belu, which is distinctive for the farming area and cannot be 
switched to another function. Therefore, he came here to approach the local community and especially, to meet Dato Lau.

"Range ini terbentuk dari pemikiran mantan Kepala Dinas Pak Yerem, dia berpikir bahwa, padang pengembala di Belu ini semakin sempit, harus ada satu kawasan di Belu ini yang khusus untuk ternak dan tidak bisa di alihkan untuk apa saja, maka pendekatan dengan masyarakat, datanglah ke sini bertemu dengan ama dato lau."

Yeremias' approach to the local traditional leader has been a proper strategy because only the leader who has a privileged right to take any decision to maintain and preserve the communal land. $\mathrm{He}$ is the chief of the ethnic Melus Alexander Lau.

This process illustrates the formation of power relations, in which a strategy has been employed to create a relationship to get access to the land for development. The change of land use, from traditional land to farming area, has potentially provided an opportunity for the ethnic group's members to take advantage of. It also attracts the government's concerns to implement their projects in the area. Some visits of Minister of State Own Company (BUMN) Dahlan Iskan and State Oil and Natural Gas Mining Company (Pertamina) indicate these interests.

The transfer of authority in land use in 2010 has been conducted formally and legalized by the handover the right over the land of sonis laloran area, from Melus community led by Alexander Lau to Yeremias. This process is witnessed by the Village Head Naekasa Manek Mikael and the Head of the West Tasifeto District Ferdinandus Bone Lau, and the other 13 witnesses.

\section{The Last Step: Marketing}

Power relation is not merely in the legislation process and the selection of location, sonis laloran. They even expand to the relationships in selling the farming product. Marketing is a social activity conducted by personal or group to achieve their goals by producing and exchanging products with other people (Darmanto, 2016). Cartel is a practice that controls the price by a certain corporation to minimalize competition (Kusuma, 2013).

Marketing here should be viewed as relations among business actors as buyers of cattle products and the farmers as sellers. In selling the product in Belu Regency, the key actor is Bernadus Lay or known as called 'old boss', who is an exporter. He initiated the business since the 1970s and exported beef cow to Java, Sumatra and neighboring countries such as Malaysia and the other neighbors.

With the interconnected interests among businessmen, local regulation, and the selection of location up to the marketing stage, is aimed at surviving family business. Issues in supporting the development of Sonis Laloran farming area are to increase the low quality of a product. The decline of the quality of farm products is due to less availability of the pasture field, which directly affects the business of exporter. Willy Lay acts as a buyer of the beef cow from the local farmers and sells it to outside their region. This illustrates the interconnection in the legislation process of local regulation that establishes the pasture field in the Village of Bakustulama as large as 500 hectares.

The development of the field has been approved in the local regulation No 6 of 2011 in chapter 5 article 29. It is also mentioned in the transfer of land of sonis laloran. The establishment of the pasture field here results in preserving the field, which directly ensures the continuation of husbandry and the availability of the product. Further, it can guarantee the supply for export business.

As a businessman, Willy Lay create relationships with the sources of power around him, then, influence the other power networks in the legislation process. Further, with the social capital and the power relations, he uses them to his 
candidacy in the local election, which he championed. Once having greater power, he expands his networks to the national level to promote his aspiration and idea to the Indonesian Vice President Jusuf Kalla. This shows how power relations are omnipresent and constantly working.

With the existence of the farming area, the local community got attention from the local authorities through projects such as grants for beef cows, farming equipment, training for feed making and reproduction of cattle, training for developing technology for farming and the health of animals. After these all processes of development and nourishment, the farming products are ready to market. The farmers sell them to the local buyers and exporters.

In the marketing process, those who are involved make an agreement in which the sellers and buyers agree for a certain price. Despite the official price per kilogram, they negotiate for the price they agree with. This negotiation for a certain price reflects practices that could be said as a cartel, which controls the price. This negotiation creates non-competitive prices made by business people by looking at chances and public demands.

There are three kinds of marketing. First, selling cattle for a traditional ceremony, such as wedding and funeral ceremonies. This kind of exchange is made based on negotiation and agreement, in which the buyer and seller negotiate for a certain price depending on the size of the cow. The one with medium size costs approximately IDR 4-7 million. In some cases, the buyer and seller agree for monthly installment payment.

Second, selling cattle for the slaughterhouse, in which the cows have been bought from local farmers through brokers, then, slaughtered and distributed to traditional marketplaces. The system of exchange is also the same, in which the buyer and seller negotiate and make an agreement for a certain price. In some cases, the farmers who need money quickly for their children's tuition fee, have negotiated for a lower price.

Third, selling to the exporter, such as business run by Willy Lay, in which he buys a lot of cows from the local farmers to be exported. In many cases he looked for a commodity in villages, approaching farmers who want to sell their cattle. Usually, the farmers sell their cattle shortly before the beginning of the new term of schools, such as in December and January, as well as June and July. Preparing children to enter a new semester at school needs the money that demands the parents to sell the cattle. Many more cases in which they sell their cattle to the ethnic Chinese traders. Willy Lay is one of them, who runs his family business in Belu. Practices of negotiation are often in this exchange.

There is no local government's intervention in this exchange. The government only controls the standard price to the local farmers, although in practices, negotiation and agreement could be made by farmers and traders. The central government provides a shipment facility (Tol Laut) to the unreached place to encourage the economic exchange and shipment of goods and commodities, which in this case is from Belu in Timor Island to the outside region.

Local traders take advantage of the facility of Tol Laut to ship their goods, which in this case is cattle. They buy the products from local farmers and export them with Tol Laut to the outside region. It is an expectation in which the government hopes Tol Laut can help local traders to run heir business and grow another business from the West Tasifeto District.

\section{CONCLUSION}

In developing local commodity of cattle farming in the West Tasifeto, there are power relations configured and played by political elites, bureaucracy, business, who have their interests and affect each other. 
In the legislation process of local regulation, power has been used to impose political bureaucratic and economic interests. The farming area or sonis laloran has been made by local regulation No. 6 of 2011, chapter 5, article 29, paragraph 1 (d), which can be said as a product of politics.

The establishment of sonis laloran is a manifestation of land-use change, from traditional land (Tanah Ulayat) to become a farming area with economic interests to expand cattle farming. In this shift, the local community and government have formed power relations, such as in transferring the land, which is connected to organizing a political campaign for the local election in 2015.

The local community in the West Tasifeto do not take maximum advantages from the expansion of the cattle farm due to ineffective marketing.

\section{ACKNOWLEDGMENT}

The author thanks everyone who has assisted this research and in writing the manuscript of this article.

\section{BIBLIOGRAPHY}

BPS. (2019). Populasi Sapi Potong menurut Provinsi, 2009-2018. Retrieved from https://www.bps.go.id/linkTableDinamis/vi ew/id/1016
Creswell, W. J. (2014). Research Design (edisi 4). Yogjakarta: pustaka pelajar.

Darmanto. (2016). Menejemen Pemasaran Untuk Mahasiswa, Usaha Mikro Kecil dan Menengah. Yogjakarta: Budi Utama.

Darmo, P. (2019). Partsipasi Masyarakat Dalam Pembentukan Peraturan Daerah Oleh DPRD Dan Pemerintah Kabupaten Propinsi Jawa Tengah (1st ed.). Yogjakarta: Budi Utama.

Hoogerwerf. (1972). politicologie:begrippen en problem. alpena: samson uitgeverij.

Kamahi, U. (2017). Teori Kekuasaan Michel Foucault: Tantangan Bagi Sosiologi Politik. Jurnal Al-Khitaba, III, 117-133.

Kusuma, L. (2013). Memahami Pengertian Kartel, Monopoli dan Persaingan Usaha. Retrieved from leo4kusuma.blogspot.com

Miriam, B. (2008). Dasar-Dasar Ilmu Politik (Edisi Revi). Jakarta: Gramedia.

Mudhoffir, A. M. (2013). Teori Kekuasaan Michel Foucault: Tantangan bagi Sosiologi Politik. Sosiologi Masyarakat, 18, 75-100.

Neno, Y. (2015). konsep kekuasaan menurut michaelfoucault. Kompasiana. Retrieved from

https://www.kompasiana.com/frenofile.co m/556085a67193731e0d8b456a/konsepkekuasaan-menurut-michael-foucault

PERDA. (2011). Peraturan Daerah Kabupaten Belu Nomor 6 Tahun 2011.

Surbakti, R. (1992). Memahami Ilmu Politik (edisi pert). Jakarta: Gramedia.

Wardah, F. (2013). Mantan Presiden PKS Divonis 16 Tahun Penjara. VOA News. Retrieved from https://www.voaindonesia.com/a/mantanpresiden-pks-divonis-16-tahunpenjara/1806711.html 